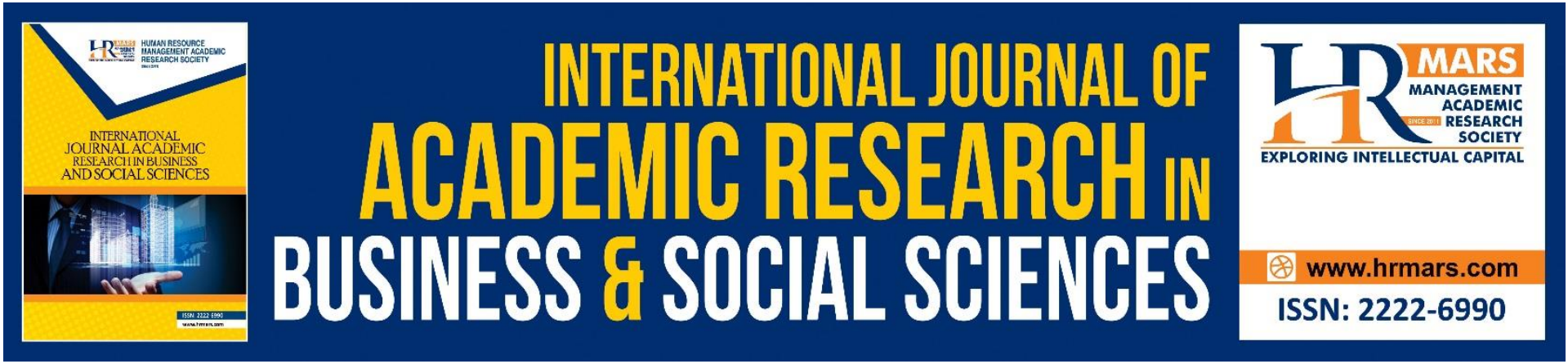

\title{
Quality of Financial Decision on Working from Home on Oil and Gas Companies in Oman
}

\section{Ali Sulaiman Alhinai, Rashed Mustafa and Thinesh Thambusamy}

To Link this Article: http://dx.doi.org/10.6007/IJARBSS/v11-i10/11274 DOI:10.6007/IJARBSS/v11-i10/11274

Received: 08 August 2021, Revised: 30 August 2021, Accepted: 15 September 2021

Published Online: 05 October 2021

In-Text Citation: (Alhinai et al., 2021)

To Cite this Article: Alhinai, A. S., Mustafa, R., \& Thambusamy, T. (2021). Quality of Financial Decision on Working from Home on Oil and Gas Companies in Oman. International Journal of Academic Research in Business and Social Sciences, 11(10), 44-51.

Copyright: @ 2021 The Author(s)

Published by Human Resource Management Academic Research Society (www.hrmars.com)

This article is published under the Creative Commons Attribution (CC BY 4.0) license. Anyone may reproduce, distribute, translate and create derivative works of this article (for both commercial and non-commercial purposes), subject to full attribution to the original publication and authors. The full terms of this license may be seen at: http://creativecommons.org/licences/by/4.0/legalcode

Vol. 11, No. 10, 2021, Pg. 44 - 51

Full Terms \& Conditions of access and use can be found at http://hrmars.com/index.php/pages/detail/publication-ethics 


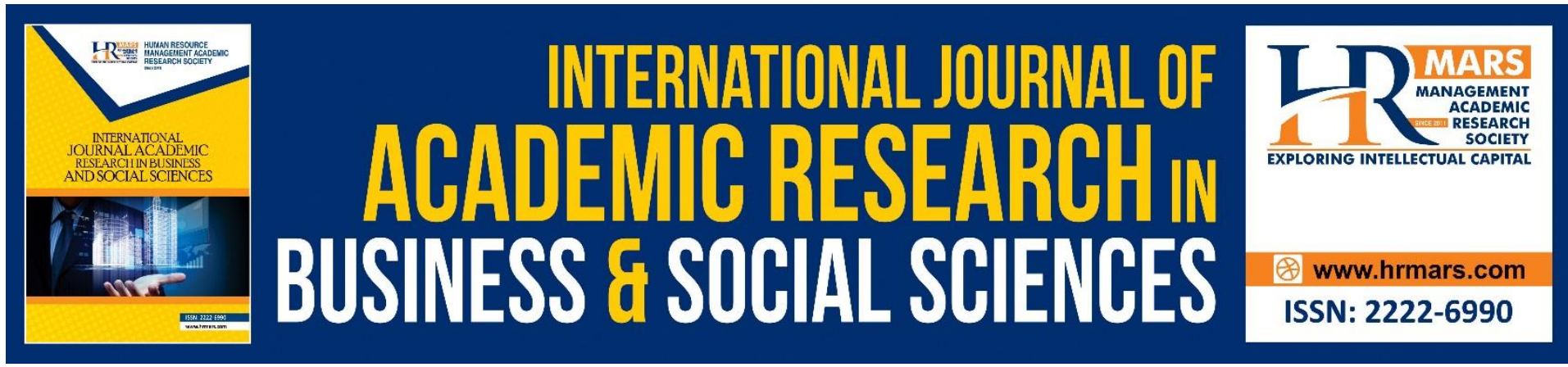

\title{
Quality of Financial Decision on Working from Home on Oil and Gas Companies in Oman
}

\author{
Ali Sulaiman Alhinai ${ }^{1}$, Dr. Rashed Mustafa ${ }^{2}$ and Dr. Thinesh \\ Thambusamy ${ }^{3}$ \\ ${ }^{1} \mathrm{PhD}$ Researcher, Binary University of Management \& Entreprenureship, Malaysia, \\ ${ }^{2}$ Professor and Dean, Department of Engineering, University of Chittagong, Bangladesh and, \\ ${ }^{3}$ Lecturer, Binary University of Management \& Entrepreneurship, Malaysia
}

\begin{abstract}
The main drive of this study is to understand the work from home (WFH) decision-making culture as well as the financial performance of Oman-based oil and gas companies. Due to the outbreak of the Covid-19 pandemic, data collected from the sector is not usually stored or distributed where it can be further used by the people of the extraction and production division. It is also necessary for the adverse situation to be recorded at the same time. Complicated production problems in the system impact the production, and thus various issues come up while analyzing data to determine historical patterns. A qualitative and quantitative approach to data collection will be followed for this study. Interviews, surveys, historical data, journals, books, and articles will be used for data collection. The study will also have thematic analysis. The healthiness of the work-from-home culture, decision-making, and financial performance of Oman's oil and gas sector will be illustrated by the expected results. It has also been observed that tech inclusion has allowed the oil and natural gas industry to explore various IT-enabled techniques.
\end{abstract}

Keywords: WFH, Coronavirus, Decision Making Culture, Financial Performance

\section{Introduction}

The new sultan of Oman had a hectic year in 2020. On $11^{\text {th }}$ January, Sultan Qaboos bin Said was succeeded by Haitham bin Tarak, a major regional player who leveraged Oman's energy wealth to transform the country from a rural backwater into a regional power broker that was modern and developed. Haitham's foreign ministry experience and plans for the latest economic reforms in Oman signify a similar talent for pragmatic evolution and maintaining peace in the region.

However, with the outbreak of COVID-19 as well as an economic crisis that is sure to speed up history, the country's commitment to progress and maintaining political neutrality will be tested again and leverage the broader global relationships of the country (Hossain et al., 2020; McKinsey, 2020).

Revenues from oil are now poised to decline further in 2020 after the pandemic set off a massive wave of falling global demand. Oman's budget manages to break even at almost \$87 
per barrel, so sub-\$30 oil, combined with a lower production quota as per the OPEC+ deal in April, implies a large budget deficit of almost $17 \%$ in 2020.

The country already entered the crisis in a fiscally weaker position than its wealthier neighbors in the Gulf Cooperation Council (GCC), who had more short-term maneuverability options with large cash reserves and access to capital markets.

Oman stood out among its GCC peers during the crisis. It no longer had the regional clout and economic stability it enjoyed only a few years prior, and these downhill trends have forced the country to diversify its investments and cultivate new relationships. The Covid-19 economic crisis will further accelerate this process. Oman's expanding global relationships are already marked by Advanced energy projects and connectivity. These can also offer the country an investment option for mitigating the economic crisis, kickstart a robust recovery process, and drive diversification in the energy sector in the backdrop of finite reserves and volatile oil markets (Nasr, Piya, \& Al-Wardi, 2020). Although the new path might not ease tensions with its GCC neighbours and American allies, a preference for cooperative economic diplomacy over military operations has already been expressed by the new sultan.

Throughout the pandemic, the oil and gas industry faced significant challenges in selling off their product and struggled with cash flow management was the oil and gas industry. Before the pandemic outbreak, the pressure to enhance financial management within the industry was already there. This research paper justifies the viability of adopting remote work as a permanent solution for Oman-based companies and how it will reduce costs, improve employee productivity, and enhance their agility. Unlike other contries, Oman's were comparatively faster to deploy WFH concept. (Purwanto et al., 2020) discovered that the most prominent and established Indonesian oil and gas companies were slow to adopt WFH. The outbreak of the pandemic could be the turning point that accelerates the lasting adoption of WFH. Hence, the purpose of this study is to understand the work from home (WFH) decisionmaking culture as well as the financial performance of Oman-based oil and gas companies in the pendamic situation.

\section{Leaders and Emerging Insights - The Return of the Strategy}

While the current crisis is consuming leadership time and attention, many leaders consider leading their companies post the end of the crisis and asking existential questions about their reasons for existing and what makes them distinct. Various strategic choices are available for leaders. These include basin master, technology specialist, value-chain integrator, midstream, trading leader, advantaged integrated refining/petrochemical player, and energy transition, specialist. It will simply be unacceptable not to take decisions that are clear and just. The multi-business model's value is usually insufficient to address poor management of operations, bad allocation of capital, or structurally disadvantaged assets. Would the larger companies be able to survive in their present form? The type of role independents and midsize players will play? How will NOCs be able to thrive and continue playing their crucial societal roles in the future?

Will the various forms of partnership within the value chain be a crucial component of business models in the future? How should companies structure relationships with other advanced analytics and tech companies to digitally transform business operations and support new business models? Could develop technology and innovation help unlock new growth for the industry: What will it take to displace coal completely by delivering new LNG projects in a fundamentally different way at $\$ 300 /$ ton (Al-Mascati \& Al-Badi, 2016)? Can CO2 mitigation costs be fundamentally reduced? In the age of abundance, will value be generated 
for those who own integrated value and customer relationships? Should companies make an effort to shift away from O\&G and renewable? (Choi, Lee \& Song, 2017)

In attempting to answer these questions, organizations must form their responses based on three facts. There has never been a better opportunity to lead - separation between laggards and market leaders will be increasingly high. Shaping regulation will be of great importance, and the enforcement of standards for operating will benefit both market and industry leaders. In the same vein, balance-sheet strength and resilience cannot be negotiated. It is essential to have a strategic view of what new capital structures (Jamadar et al., 2021) and the resultant dividend policy need to look like.

In terms of both talent and structure, companies should try to be organizations of the future. Notably, the $O \& G$ industry is not the primary employer of choice in most markets anymore and is finding it challenging to attract the best new talent in technology, digital and commercial areas (Matriano, 2021; Hossain et al., 2020). The main reasons behind this are slightly perceptual, as the young generation thinks that the oil and gas sector is on the wrong side. Nevertheless, another reason is the lack of alignment between career progression timelines and work-life balance offered by the sector and the differing expectations of the younger generation. The industry can take lessons from this crisis. The industry should try to remove existing hierarchies, lower the amount of bureaucracy, and promote edge decisionmaking-in short, adopt more agile methods of operations. A new generation of youngsters can revive innovative thinking from prior periods (Savić, 2020).

\section{The Coronavirus Crisis and the Global WFH Experiment}

In Oman, the first instance of Covid-19 was reported in March 2020. In the subsequent weeks, the authorities requested all Omani residents to stay at home, learn from home, work from home, and worship at home as the country prepared itself for the worst pandemic in recent history. An official declaration for a pandemic committee of emergency was made. Businesses throughout the country were asked to allow employees to work from their homes. The spread of the virus globally may be the turning point that reveals if companies are prepared to adapt quickly to unexpected changes at the workplace. There was either a decrease or complete stoppage of business travel.

Nevertheless, for those willing to reconsider how work will be done, they prepared why this was not done all the time. The pandemic is likely to change the operating procedures of many businesses shortly. Physical and social distancing measures have been recommended by the World Health Organization to mitigate the spread of the virus by stopping transmission chains of COVID-19 and blocking new ones from coming up (WHO, 2020). With governments worldwide asking people with symptoms to practice self-quarantine and others being asked to practice social distancing, WFH is a new reality.

The initial response to COVID-19 involved many companies introducing emergency plans to ensure the safety of their sites. Measures were put in place to provide personal protection equipment (PPE) and implement rotational shifts. Post that, a review of ongoing projects was done. These were then prioritized and readjusted as per available resources. Individuals and teams eligible for WFH were subsequently identified, and necessary role changes were made. Thus, all non-essential employees were transferred to WFH and were given laptops, cellphones, and access to data (Kramer \& Kramer, 2020). Meanwhile, site leaders developed simple infrastructure for newly adopted models of operation and routines to ensure project managers defined teams' progress. Response efforts like these were crucial for handling the 
immediate effects of the pandemic, although it soon became apparent that a total shift towards WFH was required.

\section{WFH Financial Trend During the Pandemic}

Employees are using video calls for meetings 50\% more in 2020 compared to previous years. $50 \%$ of employees would move if they were allowed to work from home part or full-time.

Since there is no commute involved, working from home saves 40 minutes per day (Fiorenzi, 2020).

$20 \%$ of employees reported doing more work during the pandemic.

Only $20 \%-25 \%$ of employees pay or share home office costs.

$75 \%$ of employees are just as productive or even more productive while working from home. It has been reported by KPMG that $70 \%$ of CEOs of large-company plan on downsizing their office space.

Indeed reports that the costs for WFH were borne by:

$55 \%$ of employees covered the costs themselves.

$27 \%$ of employees got partial assistance from their employer (Marinova, 2020).

$18 \%$ of employees were fully reimbursed.

US companies that allowed WFH has a $25 \%$ lower rate of employee turnover.

In conclusion, it can be observed from these statistics that remote working can significantly enhance the well-being and satisfaction of employees. The bottom line is, satisfied workers are more productive workers. Keeping aside productivity, offering WFH options could be a great point of selling for any organization. This also results in employees wanting to stick around for longer (Bick, Blandin, \& Mertens, 2020). Nevertheless, not everything about WFH is positive. Various challenges come with WFH.

$57 \%$ of employees in the finance industry are eligible for WFH.

It comes as no surprise that most employees who are eligible for WFH are in finance.

Companies would be able to save an average of $\$ 11,000$ every year as per half-time telecommuter

Also, considering that the lack of money is one of the top reasons that leads to the failure of small businesses, it is not overlooked. Yes, companies and employers can save too. How are they able to save, you might be asking yourself?

Well, imagine the layout of your office in your mind. There are various types of costs that are involved: internet costs, rent, and utilities. Take all of this into account, and you can visualize how companies can save money. Businesses need to ensure that they have decent software for managing workflow that ensures productivity and earns additional cash. The average yearly income earned by most telecommuters is $\$ 4000$ more than non-telecommuters (Dubey \& Tripathi, 2020). Thus, not only are telecommuters being able to save more. Telecommuters are also making more money, to begin with. As mentioned before, most of the employees working from home hold positions of authority in their respective organizations, adding to the figure. Nevertheless, it does not take into account the entirety of this deviation. Telecommuters are making decent money across the board.

A research paper published by Upwork named "Future Workforce Report" dived a bit deeper into WFH trends and discovered that $69 \%$ of the young managers, consisting mainly of millennials and some Gen Z early achievers, allow members in their team to do remote work. Even among this group, seventy-five percent of managers stated that they have workers who spend a significant part of their working hours doing remote work. 


\section{Decision Quality Matrix}

It was indicated by interview participants from OQ that IT decisions seemed to be taken in companies that were mature even within the spectrum of IT decisions. There are business issues and business problems, like on the side of the application. For example, the decisions related to IT begin from where the heading of this company is today, heading, as a single input. The position of the industry, the oil and gas industry, for example, is another input. If infrastructure-related decisions are being talked about, what is the newest offering on the side of technology? This becomes another input.

Another input in the equation is, of course, the value offered versus cost and affordability. This also factors into the decision. It also satisfies most of the criteria process for decision making.

It was stated by another participant that, once the emotion is received, it becomes a more seamless and blueprinted approach to things. Also, employees get accustomed to this way of working. Additionally, they are aware of where the decision should take place and how it should be supported. At the start, most people were not used to working in this manner; management was looked at to do all the decision-making. Further, we want to know more about the quality of build and the know-how; we want the team to provide it, the test is done with the team, and benchmarking is done to ensure it is a strong enough approach to things. Lastly, if we are satisfied, then we give the go-ahead. So it is more of a gate system that needs to be passed rather than giving the complete answer.

The IT industry and the IT teams in the oil and gas industry need to go through these cycles. When what is the latest in technology drives the decisions, they always seem to fall short. Technology is implemented without considering the problems of business and how tech can help address these issues (Hossain et al., 2021; San et al., 2020) If it is successful, it is matched to where the business is heading.

To show how the decision quality matrix was implemented and maintained in their respective organizations, the researchers conducted a survey using Google forms and targeted Oil \& Gas employees in Oman using a Likert scale (1-5). One represents totally disagree, while five represents totally agree. Three weeks was the duration of the survey, and 109 was the number of respondents. The survey showed that the matrices are above average, which indicates a mature level implementation of the decision quality matrix.

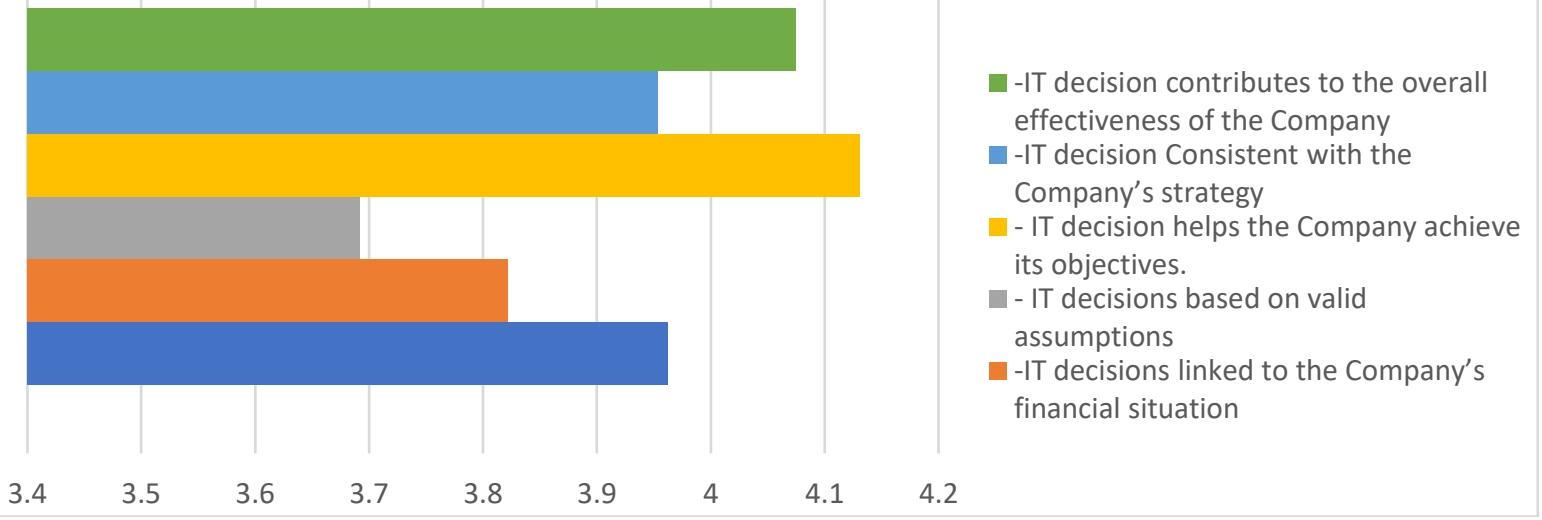

Figure.1: Survey of average responses of decision quality matrix

\section{Impact of Covid-19 on Financial Performance of O\&G in Oman}

Historical data from one of Oman's large O\&G companies reveals an improvement in financial performance in 2021 after the dreadful 2020. 
As the company concluded its third quarter and entered the fourth quarter, it remained strong financially despite all challenges and continued to implement its growth project as planned. Cases of Covid-19 were rising again globally, and as a result, there could be another fall in demand for crude. Combined with elections in the United States, this time of uncertainty pushed front-month Brent futures below $\$ 40$ per barrel, and prices are still under pressure. When the third quarter comes to a close, and core assets below budget recorded EBITDA of $-55 \%$, but $40 \%$ above the latest estimates, OpEx savings across businesses positively impacted the September 2020 results. OQ Scored 31.5\% out of applicable KPIs for this period. In April 2021, the company witnessed recovery, with prices of crude rebounding to prepandemic levels during the month. Similarly, after reaching multi-year lows in the second quarter of 2020, economic activity has increased significantly. As OQ GCEO explained, "However, there are still lingering concerns with the number of Covid cases surging in some major oil-consuming countries, such as India and Brazil. We are continuously monitoring the situation and making decisions accordingly".

However, $\mathrm{OQ}$ had a more decisive month, financially and operationally, due to the combination of higher prices, demand recovery, and lower costs led. Year to date (YTD), the company generated a consolidated EBITDA of 32\% of the target for the entire year, with Net Profits already exceeding the full-year target for 2021.

Moreover, the monthly performance of the June 2021 review revealed a good EBITDA performance as implied by the GCEO "Financially, I am pleased that the improving market sentiments are well reflected in performance, as we ended May with a consolidated EBITDA of more than half of the full-year budget. On the other hand, the the company scorecard displayed $92.7 \%$ of the applicable KPI. Net profit was remarkable."

\section{Conclusion}

In conclusion, the research from home statistics reveals that remote work is not going anywhere. WFH has witnessed an uphill trend for nearly two decades, with no end in view. Nevertheless, it does not imply that WFH does not have its fair share of difficulties. This becomes especially apparent for specific sectors, for instance, Oil \& Gas. However, WFH has much potential in other industries.

In today's date, it has become more crucial than ever to explore multiple options. Ranging from potential cost-cutting to diversification of the workforce, WFH can give an edge to companies. Also, it can grant more flexibility and freedom than ever before for an employee. Oman O\&G companies have survived the challenges brought on by COVID-19 by being agile, proactive, and flexible while leveraging its excellent IT infrastructure setup, work from home concept with $30 \%$ office-based work from the start of the pandemic and decision quality matrix.

\section{References}

Al-Mascati, H., \& Al-Badi, A. H. (2016). Critical success factors affecting the adoption of cloud computing in oil and gas industry in Oman. In 2016 3rd MEC International Conference on Big Data and Smart City (ICBDSC) (pp. 1-7). IEEE.

Bick, A., Blandin, A., \& Mertens, K. (2020). Work from home after the COVID-19 outbreak.

Choi, Y., Lee, C., \& Song, J. (2017). Review of renewable energy technologies utilized in the oil and gas industry. International Journal of Renewable Energy Research, 7(2), 592-598. 
Dubey, A. D., \& Tripathi, S. (2020). Analysing the sentiments towards work-from-home experience during covid-19 pandemic. Journal of Innovation Management, 8(1), 1319.

Fiorenzi, R. (2020). 57 Work from Home Statistics that May Surprise You. Start Standing. Retrieved 27th July 2021, from https://www.startstanding.org/work-from-homestatistics/\#.

Hossain, M. I., Polas, M. R. H., Rahman, M. M., Islam, T., \& Jamadar, Y. (2020). An Exploration of COVID-19 Pandemic and its Consequences on FMCG Industry in Bangladesh. Journal of Management Info, 7(3), 145-155. https://doi.org/10.31580/jmi.v7i3.1484

Hossain, M. I., San, O. T., Ling, S. M., \& Said, R. M. (2020). The Role of Environmental Awareness and Green Technological Usage to Foster Sustainable Green Practices in Bangladeshi Manufacturing SMEs. International Journal of Advanced Science and Technology. 29 (7s), 3115-3124.

Hossain, M. I., San, O. T., Ling, S. M., Said, R. M., \& The, B. H. (2021). Nexus of Stakeholder Integration, Environmental Investment, Green Technology Adoption and Environmental Sustainability Practices:

Evidence from Bangladesh Textile SMEs. Journal of Social Sciences and Humanities. [On press]

Jamadar, Y., San, O. T., Abdullah, A. A., \& Kamarudin, F. (2021). Earnings and discretionary accruals. Managerial and Decision Economics. Doi: https://doi.org/10.1002/mde.3391

Kramer, A., \& Kramer, K. Z. (2020). The potential impact of the Covid-19 pandemic on occupational status, work from home, and occupational mobility.

Marinova, I. (2020). 2021's Remote Work Statistics (Productivity, Income, Trends). Review42. Retrieved 27th July 2021, from https://review42.com/resources/remote-workstatistics.

Matriano, M. (2021). The Impact of Online Work on the Operating Costs of Petroleum Development Oman (PDO). International Journal of Research in Entrepreneurship \& Business Studies, 2(3), 57-64.

McKinsey. (2020). Oil and gas after COVID-19: The day of reckoning or a new age of opportunity?. mckinsey.com. Retrieved 27th July 2021, from https://www.mckinsey.com/industries/oil-and-gas/our-insights/oil-and-gas-aftercovid-19-the-day-of-reckoning-or-a-new-age-of-opportunity.

Nasr, A. H., Piya, S., \& Al-Wardi, K. (2020). Analysis of factors affecting motivation in projects: A case study in oil and gas industry in Oman. The Journal of Engineering Research [TJER], 17(2), 112-125.

Purwanto, A., Asbari, M., Fahlevi, M., Mufid, A., Agistiawati, E., Cahyono, Y., \& Suryani, P. (2020). Impact of work from home (WFH) on Indonesian teachers performance during the Covid-19 pandemic: An exploratory study. International Journal of Advanced Science and Technology, 29(5), 6235-6244.

San, O. T., Teh, B. H., Kasbun, N. F., Mahroeian, H., Hossain, M. I. (2020). Electronic Commerce Adoption among Malaysian SMEs. Journal of Critical Reviews. 7(19), 555565.

Savić, D. (2020). COVID-19 and work from home: Digital transformation of the workforce. Grey Journal (TGJ), 16(2), 101-104. 